\title{
A Fuzzy Evaluation Model of College English Teaching Quality Based on Analytic Hierarchy Process
}

\author{
https://doi.org/10.3991/ijet.v16i02.19731 \\ Nan Li \\ Xingtai University, Xingtai, China \\ nym200798@126.com
}

\begin{abstract}
The evaluation of English teaching quality in colleges mainly faces two problems: the evaluation index system (EIS) is incomplete, and the evaluation model cannot easily handle complex fuzzy indices. To solve the problems, this paper explores deep into the fuzzy evaluation of college English teaching quality, and establishes a fuzzy evaluation model of college English teaching quality based on analytic hierarchy process (AHP). Firstly, theoretical analysis was combined with model calculation to create an improved multi-angle EIS for college English teaching quality. From both quantitative and qualitative analyses, a college English teaching quality evaluation model was constructed to handle fuzzy indices. Implementation results show that the proposed EIS and fuzzy evaluation model can effectively assess the quality of English teaching in colleges. The research results greatly promote the quality improvement of college English teaching.
\end{abstract}

Keywords - Teaching quality, English teaching, higher education, analytic hierarchy process (AHP), fuzzy evaluation

\section{Introduction}

Current higher education attaches great importance to the comprehensive quality training of senior talents [1-2]. For countries with non-English mother tongue, the training of college students includes not only solid professional knowledge and skills, but also good English capacity in colleges, to promote the exchange and development of senior talents. For this, it is very important to improve high-quality English teaching in colleges and cultivate senior talents with outstanding English ability [3-5]. However, English teaching in colleges is often subjected to various factors such as English teachers, English teaching and scientific research, English teaching management systems and mechanisms, English teaching concepts, teaching approaches, teaching methods, social factors, human factors, material factors and financial factors, which make it more difficult and complex to improve and assess the English teaching quality in colleges [69]. In view of this, some scholars have carried out corresponding researches on the improvement and evaluation of English teaching quality. For example, Rus discussed innovative teaching methods in engineering English teaching in order to improve the quality of English teaching [10]. Petra conducted a research on the need analysis and 
quality assessment in medical English teaching [11]. Yan et al. analyzed the construction of a SPOC-based evaluation index system for college English teaching quality [12]. Zhang proposed an English teaching quality evaluation model based on GA optimized RBF neural network [13]. Wang and Song probed into a fuzzy evaluation method of English teaching quality based on the bat algorithm [14].

However, it should be noted that the improvement and evaluation of English teaching quality in colleges is a fuzzy system decision-making analysis process that is affected by many conditions and factors. For different researchers, the analysis perspectives and evaluation standards are not consistent. Also, the relevant evaluation indices are fuzzy. Thus, there often have certain limitations in the evaluation methods of English teaching quality in colleges.

As above, this paper probes into the evaluation of English teaching quality in colleges based on AHP method [15-16] and grey system theory [17-18], and proposes an improved evaluation index system and a fuzzy evaluation model of college English teaching quality. It consists of 4 parts. The first part briefly analyzes the problems existing in the process of college English teaching and the related research content on the teaching process and teaching quality; the second part discusses the essential problems of the English teaching quality evaluation in colleges based on AHP from six aspects, and establishes a new EIS; the third part establishes an improved evaluation model of college English teaching quality based on the integration of AHP method and grey system theory; the last part gives the main research conclusions of this paper.

\section{Establishing a New Evaluation Index System of English Teaching Quality in Colleges}

To implement the modern higher education model effectively, the college English teaching should be closely integrated with the current development characteristics of the times. It must not only meet the modern society's demand for senior English talents, but also consider the current English teaching situation in colleges. Thus, the development of English teaching in colleges is a dynamic, developmental, and systematic process. In this process, the college English teaching quality is restricted by a variety of dynamic, developmental, and systemic factors, which should be taken into consideration in the establishment of the EIS for college English teaching quality correspondingly. In this paper, the authors proposed to establish the EIS of English teaching quality in colleges from the comprehensive aspects of teaching link, learning link, management link, innovation factor, integration factor, and factor of teaching results.

\subsection{The evaluation index sub-system of college English teaching quality based on the teaching of English teachers}

The teaching of professional teachers in colleges focuses on their English teaching ability, which includes both the basic professional ability of English teachers and the application of relevant measures to improve the teaching ability of English teachers. From the teaching process in colleges, English teaching involves different links such as 
listening, reading, speaking, writing, and translation. Each link is related to the professional ability requirements of the individual English teachers, the basic inputs in professional teaching, the construction of the English teaching system, and the English teaching organization planning. For this, the authors propose to comprehensively consider the following factors when establishing the evaluation index subsystem of college English teaching based on the teaching of professional teachers: the number of highlevel English teachers, professional quality and level of English teachers, systematicness of English course materials, the epochal character of English teaching objectives and the syllabus, basic input of English teaching, and teaching effect of English classrooms, as shown in Table 1 for details.

Table 1. The evaluation index sub-system $C_{l}$ of college English teaching quality based on the teaching of professional teachers

\begin{tabular}{|l|l|l|c|}
\hline \multicolumn{1}{|c|}{ Index } & \multicolumn{1}{c|}{ Type } & \multicolumn{1}{c|}{ Category } & Symbol \\
\hline Number of high-level/high-title English teachers & Quantitive & Positive index & $C_{11}$ \\
\hline Professional ability and level & Qualitative & Positive index & $C_{12}$ \\
\hline Systematicness of English course materials & Qualitative & Positive index & $C_{13}$ \\
\hline $\begin{array}{l}\text { The epochal character of English teaching objectives and the } \\
\text { syllabus }\end{array}$ & Qualitative & Positive index & $C_{14}$ \\
\hline Basic inputs of English teaching & Qualitative & Positive index & $C_{15}$ \\
\hline Teaching effect of English classroom & Qualitative & Positive index & $C_{16}$ \\
\hline
\end{tabular}

\subsection{The evaluation index sub-system of college English teaching quality based on the learning of students}

The learning link focuses on the learning ability of college English students, including the ability to learn basic knowledge of English and the ability to deal with the learning problems. Modern society is in an information age with an explosion of knowledge. In different stages of English listening, reading, speaking, writing, and translation, English learning is often flooded with various types of professional knowledge and problems. Due to the changeability and development of social information, lots of English professional knowledge needs to be obtained by English learners through adequate preclass preparation and extracurricular study, i.e., the college English learners should possess a strong sense of self-learning. Therefore, the learning of English learners in colleges needs to be analyzed from the independent learning ability, learning initiative, learning interest, the ability to find problems, the ability to solve problems independently, and the ability to solve expanded problems, as shown in Table 2 for details. 
Table 2. The evaluation index sub-system $C_{2}$ of college English teaching quality based on students' learning

\begin{tabular}{|l|l|l|c|}
\hline \multicolumn{1}{|c|}{ Index } & \multicolumn{1}{c|}{ Type } & \multicolumn{1}{c|}{ Category } & Symbol \\
\hline The independent learning ability of English & Qualitative & Positive index & $C_{21}$ \\
\hline Learning initiative & Qualitative & Positive index & $C_{22}$ \\
\hline English learning interest & Qualitative & Positive index & $C_{23}$ \\
\hline The ability to find problems & Qualitative & Positive index & $C_{24}$ \\
\hline The ability to solve problems & Qualitative & Positive index & $C_{25}$ \\
\hline The ability to solve expanded problems & Qualitative & Positive index & $C_{26}$ \\
\hline
\end{tabular}

\subsection{The evaluation index sub-system of college English teaching quality based on professional teaching management}

The professional teaching management of English in colleges focuses on the management ability of managers and the completeness of management systems in college English teaching. It can be found that the management ability of leading teachers and managers in college English curriculum will directly affect the implementation of English teaching decisions, and inevitably have an important impact on the quality of English teaching. Meanwhile, as the direct participants and makers of the English curriculum teaching management system, the leading teachers and managers will affect the formulation and implementation of related systems for the teaching management, while the English teaching management system is an important guarantee for the smooth implementation of teaching. Therefore, the English teaching management in colleges needs to reflect the level and ability of English teaching management, the completeness and expansibility of English teaching management system, the completeness and expansibility of English teaching reward and punishment mechanism, and system completeness and expansibility of English teaching resource utilization, as shown in Table 3 for details.

Table 3. The evaluation index sub-system $C_{3}$ of college English teaching quality based on teaching management

\begin{tabular}{|l|l|l|c|}
\hline \multicolumn{1}{|c|}{ Index } & \multicolumn{1}{c|}{ Type } & \multicolumn{1}{c|}{ Category } & Symbol \\
\hline Level and ability of English teaching management & Qualitative & Positive index & $C_{31}$ \\
\hline $\begin{array}{l}\text { Completeness and expansibility of English teaching management } \\
\text { system }\end{array}$ & Qualitative & Positive index & $C_{32}$ \\
\hline $\begin{array}{l}\text { Completeness and expansibility of English teaching reward and } \\
\text { punishment mechanism }\end{array}$ & Qualitative & Positive index & $C_{33}$ \\
\hline $\begin{array}{l}\text { System Completeness and expansibility of English teaching re- } \\
\text { source utilization }\end{array}$ & Qualitative & Positive index & $C_{34}$ \\
\hline
\end{tabular}

\subsection{The evaluation index sub-system of college English teaching quality based on the innovation of English teaching}

The innovation of English teaching in colleges focuses on the transformability and improving ability of relevant teaching factors to improve the English teaching quality in the teaching course of college English. From the development process of modern 
higher education, following the continuous development of intelligent technology, modern intelligent education technology has played an increasingly important role in the development of education, and produced huge impacts on the English teaching of modern education in terms of teaching means, teaching methods, teaching concepts, teaching approaches, and teaching content, etc. Due to the combined effect of these factors, the English teaching of modern higher education will inevitably be filled with the inherent demand for continuous change and improvement, while these factors will be directly reflected in the professional curriculum settings and the configuration of software and hardware facilities for English teaching in colleges. Nevertheless, the human factor is more a manifestation of the manager's staged planning, which is generally unsustainable, that is, its planning for English teaching is not systematic and sustainable. For this reason, excluding the human influence factors, the innovative ability of college English teaching will be more reflected in the hardware facilities and curriculum system construction of English teaching, as shown in Table 4 for details.

Table 4. The evaluation index sub-system $C_{4}$ of college English teaching quality based on the innovation of English teaching

\begin{tabular}{|l|l|l|c|}
\hline \multicolumn{1}{|c|}{ Index } & \multicolumn{1}{|c|}{ Type } & \multicolumn{1}{c|}{ Category } & Symbol \\
\hline $\begin{array}{l}\text { The number of key teaching and research offices for } \\
\text { English teaching based on intelligent educational } \\
\text { technology }\end{array}$ & Quantitive & Positive index & $C_{41}$ \\
\hline $\begin{array}{l}\text { The number of English teaching innovation experi- } \\
\text { mental projects that college English teachers under- } \\
\text { take, organize or mainly participate in }\end{array}$ & Quantitive & Positive index & $C_{42}$ \\
\hline $\begin{array}{l}\text { Number of high-level English teaching reform pro- } \\
\text { jects }\end{array}$ & Quantitive & Positive index & $C_{43}$ \\
\hline $\begin{array}{l}\text { The number of excellent English courses in the new } \\
\text { era }\end{array}$ & Quantitive & Positive index & $C_{44}$ \\
\hline Construction of English learning base & Qualitative & Positive index & $C_{45}$ \\
\hline
\end{tabular}

\subsection{The evaluation index sub-system of college English teaching quality based on the integration of English teaching}

The integration of English teaching in colleges focuses on the integration of theoretical knowledge and practical knowledge, the integration of English teaching and scientific research, and the integration of campus factors and social development and demand factors of English teaching in different links of college English teaching such as English listening, reading, speaking, writing and translation. As a language-based teaching, English teaching in colleges has played a more significant role in the global economic integration, which will further promote the role of English language, expand the application fields, and improve the teachers' awareness of practicality, sociality, and scientific research during the process of English teaching. Therefore, the integration of English teaching in colleges was analyzed in this study from different aspects: social practice of English teaching, professional knowledge competition, the transformation of English scientific research results into the teaching process, and social recognition, as shown in Table 5 for details. 
Table 5. The evaluation index sub-system $C_{5}$ of college English teaching quality based on the integration of English teaching

\begin{tabular}{|l|l|l|c|}
\hline \multicolumn{1}{|c|}{ Index } & \multicolumn{1}{c|}{ Type } & \multicolumn{1}{c|}{ Category } & Symbol \\
\hline The number of social practices in English teaching & Quantitive & Positive index & $C_{51}$ \\
\hline $\begin{array}{l}\text { Number of professional knowledge competitions organized/mainly } \\
\text { participated in English teaching }\end{array}$ & Quantitive & Positive index & $C_{52}$ \\
\hline Transformation rate of English scientific research results & Quantitive & Positive index & $C_{53}$ \\
\hline Social recognition of English teaching & Quantitive & Positive index & $C_{54}$ \\
\hline
\end{tabular}

\subsection{The evaluation index sub-system of college English teaching quality based} on the teaching results

The teaching results are the most direct manifestation of the implementation effect in college English teaching. It is also a quantitative factor that can be more easily captured. College students are the main performance objects reflecting the implementation effect of college English teaching. Therefore, the evaluation of college English teaching results mainly focuses on the improvement of the students' comprehensive ability and the quantitative analysis of academic performance. Therefore, college English teaching results should include college English students' academic performance and professional competence, as shown in Table 6 for details.

Table 6. The evaluation index sub-system $C_{6}$ of college English teaching quality based on the teaching results

\begin{tabular}{|l|l|l|c|}
\hline \multicolumn{1}{|c|}{ Index } & \multicolumn{1}{|c|}{ Type } & \multicolumn{1}{c|}{ Category } & $\begin{array}{c}\text { Sym- } \\
\text { bol }\end{array}$ \\
\hline Failure rate of English scores & Quantitive & $\begin{array}{c}\text { Negative } \\
\text { index }\end{array}$ & $C_{61}$ \\
\hline Pass/excellence rate of English scores & Quantitive & Positive index & $C_{62}$ \\
\hline Number of awards in high-level English competitions & Quantitive & Positive index & $C_{63}$ \\
\hline Employment rate of college English students & Quantitive & Positive index & $C_{64}$ \\
\hline The academic innovation level of college English majors & Qualitative & Positive index & $C_{65}$ \\
\hline $\begin{array}{l}\text { Professional quality level of college English majors } \\
\text { Professional knowledge application ability of college English ma- } \\
\text { jors }\end{array}$ & Qualitative & Positive index & $C_{66}$ \\
\hline
\end{tabular}

\subsection{A hierarchical evaluation index system of college English teaching quality}

To sum up, the EIS of college English teaching was constructed from multiple perspectives such as the teaching, learning, management, innovation, integration, and specific teaching results. Let the EIS of college English teaching be $C$, then the hierarchical framework diagram of the EIS was obtained, as shown in Figure 1. 


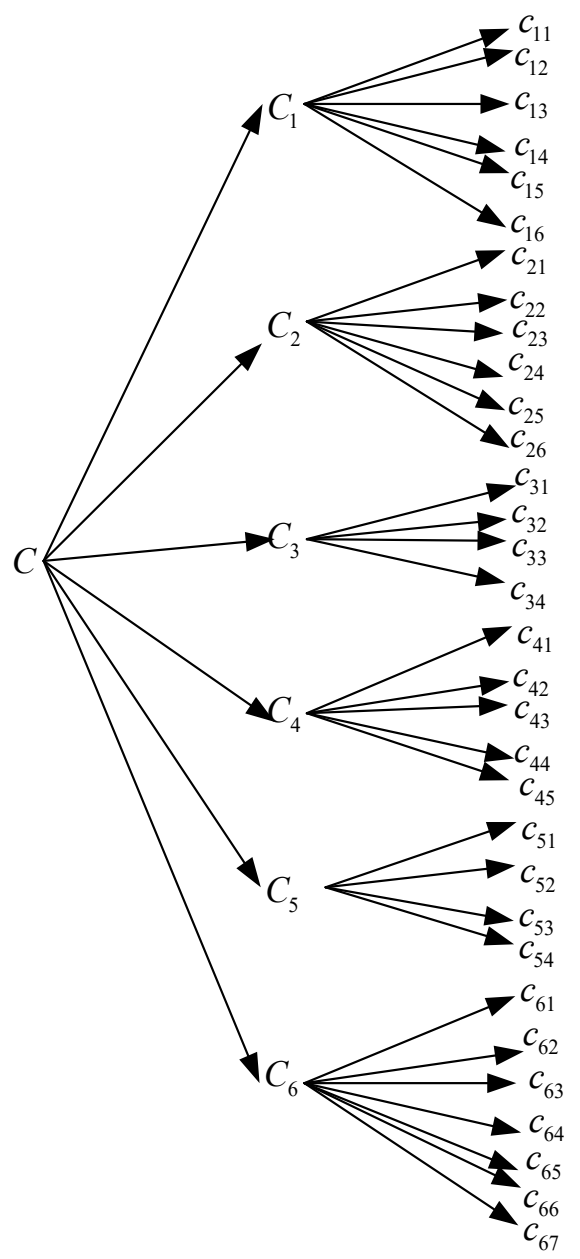

Fig. 1. The hierarchical framework of the evaluation index system for English teaching quality in colleges

\section{Establishing an Evaluation Model of College English Teaching Quality Based on AHP and Grey System Theory}

\subsection{Standardized processing of evaluation indices}

Based on the hierarchical EIS of college English teaching quality above, there are two categories of evaluation indices: positive index and negative index. For the former, the larger the corresponding index value obtained, the higher the college English teaching quality level of the relevant evaluation object; for the latter, the larger the corresponding index value obtained, the lower the teaching quality level. The two 
categories of evaluation indices were standardized on the same evaluation scale, to unify their evaluation standard, and ensure more accurate evaluation results of college English teaching quality.

It's given that the maximum value of the $j$-th evaluation index in the EIS of college English teaching quality is $V_{j}(\max )$, the minimum value is $V_{j}(\min )$, and the initial value of the $j$-th evaluation index for the evaluation object $O$ is $V_{j}(\mathrm{O})$. If it's a positive index, its standardized value is $R_{j}(O)$,

$$
R_{j}(O)=\frac{V_{j}(O)-V_{j}(\min )}{V_{j}(\max )-V_{j}(\min )}
$$

If the $\mathrm{j}$-th evaluation index is a negative one, its standardized value is $R_{j}(O)$ :

$$
R_{j}(O)=\frac{V_{j}(\max )-V_{j}(O)}{V_{j}(\max )-V_{j}(\min )}
$$

In particular, if the initial value of this evaluation index for the evaluation object $\mathrm{O}$ is a fuzzy value, that is, $V_{j}(O)=\left[v_{j}^{a}(O), v_{j}^{b}(O)\right], v_{j}^{a}(O) \leq v_{j}^{b}(O)$, then as a positive index, its standardized value is $R_{j}(O)$ :

$$
R_{j}(O)=\left[r_{j}^{a}(O), r_{j}^{b}(O)\right]=\left[\frac{v_{j}^{a}(O)-V_{j}(\min )}{V_{j}(\max )-V_{j}(\min )}, \frac{v_{j}^{b}(O)-V_{j}(\min )}{V_{j}(\max )-V_{j}(\min )}\right]
$$

When the $j$-th evaluation index is a negative one, its standardized value is $R_{j}(O)$ :

$$
R_{j}(O)=\left[r_{j}^{a}(O), r_{j}^{b}(O)\right]=\left[\frac{V_{j}(\max )-v_{j}^{b}(O)}{V_{j}(\max )-V_{j}(\min )}, \frac{V_{j}(\max )-v_{j}^{a}(O)}{V_{j}(\max )-V_{j}(\min )}\right]
$$

\subsection{AHP-based index weighting}

For the $j$-th evaluation index in the EIS at different evaluation stages and perspectives, its role in the evaluation process of college English teaching quality often varies. If this index has a significant impact on the evaluation results of college English teaching quality, it can greatly promote the college English teaching quality, and has greater weight in the evaluation process. Due to its characteristics of simple calculation, high reliability, and clear physical meaning in the process of obtaining index weights, the AHP method was used in this paper to acquire the weights of college English teaching quality evaluation indices [19-21].

Besides, the experts in the professional field of college English teaching were invited to score and compare the importance of college English teaching quality evaluation indices using a measurement ratio of $1-9$, and give the differences in the evaluation 
indices between the colleges. Thus, the evaluation matrix $\boldsymbol{Q}$ was constructed according to the evaluation index weight of college English teaching quality.

$$
\mathbf{Q}=\left[q_{i j}\right]_{n \times n}=\left[\begin{array}{cccc}
q_{11} & q_{12} & \cdots & q_{1 n} \\
q_{21} & q_{22} & \cdots & q_{2 n} \\
\vdots & \vdots & \cdots & \vdots \\
q_{n 1} & q_{n 2} & \cdots & q_{n n}
\end{array}\right]
$$

where, $n$ is the number of evaluation indices for college English teaching quality, and $q_{i j}$ is the importance of the $i$-th evaluation index relative to the $j$-th evaluation index; the larger the evaluation index $q_{i j}$, the greater the role of the $i$-th evaluation index, and $q_{i j}=$ $\frac{1}{q_{j i}}$.

It can be found that the size of the value $q_{i j}$ directly determines the weight distribution of the evaluation index for college English teaching quality. When assigning the value $q_{i j}$, it's necessary to accurately determine the relationship between the $i$-th and the $j$-th evaluation indices. Table 7 lists specific meanings of $q_{i j}$.

Table 7. Meanings of $q_{i j}$

\begin{tabular}{|c|l|}
\hline $\mathbf{q}_{\mathrm{ij}}$ & \multicolumn{1}{|c|}{ Meanings } \\
\hline 1 & The same importance of the two evaluation indices \\
\hline 3 & The importance of the former evaluation index is slightly higher than the latter \\
\hline 5 & The importance of the former evaluation index is higher than the latter \\
\hline 7 & The importance of the former evaluation index is much higher than the latter \\
\hline 9 & The importance of the former evaluation index is extremely higher than the latter \\
\hline $2,4,6,8$ & In an intermediate state between the above two adjacent importance \\
\hline Reciprocal relationship & \\
\hline
\end{tabular}

Based on the established evaluation matrix $\mathrm{Q}$ of evaluation index weights, the authors obtained the largest eigenvector and the corresponding eigenroot $\lambda(\boldsymbol{Q})_{\max }$ through the Matlab calculation module, and then the consistency index $C I$.

$$
C I=\frac{\lambda_{\max }(\mathbf{Q})-n}{n-1}
$$

According to the number of evaluation indices for college English teaching quality, the random consistency index RI was obtained by looking up the table, and the corresponding consistency ratio $\mathrm{CR}$ coefficient was calculated as:

$$
C R=\frac{C I}{R I}=\frac{\lambda_{\max }(\mathbf{Q})-n}{R I *(n-1)}
$$

Consistency test was also conducted on the evaluation matrix Q. If it satisfies, 


$$
C R<0.1
$$

then, it indicates that the evaluation matrix $\boldsymbol{Q}$ meets the consistency requirements; otherwise, $\boldsymbol{Q}$ does not meet the consistency requirements, and the college English teaching quality evaluation index weights obtained will not meet the evaluation requirements. Thus, it's necessary to rebuild the evaluation matrix according to the consistency test requirements.

On the basis of satisfying the requirements of the consistency test, the weight $w_{j}$ of the $j$-th evaluation index for college English teaching quality is given as:

$$
w_{i}=\frac{\left(q_{i j} / \sum_{j=1}^{n} q_{i j}\right)}{\sum_{i=1}^{n}\left(q_{i j} / \sum_{j=1}^{n} q_{i j}\right)}
$$

\subsection{Generating the grey sequence of English teaching quality evaluation index in colleges}

To meet the actual needs in the evaluation process, the teaching quality of college English was classified into $m$ grades. Then, the value fuzzy interval of the $j$-th evaluation index in the i-th teaching quality grade is:

$$
R_{j}^{i}(G)=\left[r_{j}^{i-a}(G), r_{j}^{i-b}(G)\right], \quad r_{j}^{i-a}(G) \leq r_{j}^{i-b}(G), \quad 1 \leq i \leq m
$$

According to the grey system theory, it can be known that the grey reference sequence of the $\mathrm{j}$-th evaluation index at the $\mathrm{i}$-th evaluation grade is given as:

$$
\mathbf{R}^{i}(G)=\left\{R_{1}^{i}(G), \cdots, R_{j}^{i}(G), \cdots, R_{n}^{i}(G)\right\}
$$

Similarly, on the basis of obtaining the $\mathrm{j}$-th evaluation index value for the evaluation object $\mathrm{O}$, the grey comparison sequence is established accordingly:

$$
\mathbf{R}(O)=\left\{R_{1}(O), \cdots, R_{j}(O), \cdots, R_{n}(O)\right\}
$$

\subsection{Implementing grey relational decision analysis algorithm for English teaching quality in colleges}

Through the above calculation and analysis, the fuzzy distance between the j-th evaluation index and $R_{j}^{i}(G)$ for the evaluation object $\mathrm{O}$ was obtained, namely,

$$
D_{j}^{i}(G)=\frac{\left|R_{j}(O)-r_{j}^{i-a}(G)\right|+\left|R_{j}(O)-r_{j}^{i-b}(G)\right|}{2}
$$


Based on the grey relational analysis method [22-26], the grey relational coefficient between the $\mathrm{j}$-th evaluation index and $\mathrm{Ri}(\mathrm{G})$ for the evaluation object $\mathrm{O}$ is expressed as:

$$
\rho_{j}^{i}(G)=\frac{\min _{i} \min _{j} D_{j}^{i}(G)+\beta * \max _{i} \max _{j} D_{j}^{i}(G)}{D_{j}^{i}(G)+\beta * \max _{i} \max _{j} D_{j}^{i}(G)}
$$

where, $\beta \in[0,1]$, and it represents the resolution coefficient, generally $\beta=0.5$; $\operatorname{minmin}_{i} D_{j}^{i}(G)$ represents the double-minimum processing of the fuzzy distance $D_{j}^{i}(G) ; \max _{i} \max _{j} D_{j}^{i}(G)$ represents the double-maximum processing of $D_{j}^{i}(G)$.

Taking the corresponding weights of each evaluation index into comprehensive consideration, the comprehensive weighted grey correlation degree between the evaluation object $\mathrm{O}$ and $\mathrm{Ri}(\mathrm{G})$ is given as:

$$
\psi^{i}(O)=\sum_{j=1}^{n}\left(w_{j} * \rho_{j}^{i}(G)\right)
$$

According to the optimization principle of grey relational decision analysis, if it satisfies:

$$
\psi^{k}(O)=\underset{1 \leq i \leq m}{\max }\left\{\psi^{i}(O)\right\}, \quad 1 \leq k \leq m
$$

Then English teaching quality of the evaluation object $\mathrm{O}$ was at the k-th evaluation level.

The evaluation model of college English teaching quality established above can help to accurately and quantitatively analyze the English teaching quality of the evaluation object $O$, and further obtain the corresponding teaching quality grade. If the English teaching quality of the evaluation object $O$ can meet the requirements of English teaching, then the corresponding English teaching process is feasible; otherwise, it means that some teaching links in the corresponding English teaching process have limitations and problems, and targeted teaching measures should be adopted. Combining the actual situation of English teaching in colleges and the related factors affecting the English teaching quality, the authors propose some strategies to improve the English teaching quality in colleges, i.e., increase the inputs in the basic conditions of English teaching in colleges, strengthen the construction of English teaching talents, enhance the international communication ability of college English teaching, improve the comprehensive professional ability and quality of college English teachers, expand the perspective of college English teaching, reinforce the practicality of college English teaching, deepen the integration between college English teaching and scientific research, promote the teaching management system under the new situation, improve the college English teaching reform and innovation ability, enhance the organization and planning ability of college English teaching in the new situation, enrich the curriculum content and course system construction of college English teaching, and 
strengthen the cultivation of autonomous learning in college English teaching under the new situation etc.

\section{Conclusion}

1. This paper analyzes the evaluation index system of college English teaching from the aspects of teaching, learning, management, innovation factors, fusion factors, and specific results content in the process of college English teaching, and proposes to establish a more systematic and complete EIS, which is of great guiding significance for building a new comprehensive EIS of English teaching quality in colleges.

2. Based on the AHP method and grey system theory, a fuzzy evaluation model was established for the evaluation of college English teaching quality, which not only clarifies the physical meaning of college English teaching quality evaluation, but also ensure a simple and reliable calculation. This provides a way and method of quantitative analysis for the evaluation of college English teaching quality.

3. Using the improved EIS and the fuzzy evaluation model for the English teaching quality in colleges, this paper also conducts a preliminary discussion on the relevant strategies to improve college English teaching quality, which has certain referential value for the improvement of college teaching quality.

\section{$5 \quad$ References}

[1] Peña-Ayala, A., Villegas-Berumen, H.G. (2020). Evaluation of the influence that higher education boosts on students' entrepreneurial proclivity: Evidence from Mexico and Spain. The International Journal of Management Education, 18(3): 1-21. https://doi.org/10.1016/j. ijme.2020.100404

[2] Matsuoka, R. (2019). Concerted cultivation developed in a standardized education system. Social Science Research, 77: 161-178. https://doi.org/10.1016/j.ssresearch.2018.08.011

[3] Pang, J.Q. (2019). A Probe into English Language Teaching in ASEAN Countries Based on Pedagogics and its Revelation. Journal of Nanning Polytechnic, 24(3): 27-30. https://doi.org/10.3969/j.issn.1009-3621.2019.03.008

[4] Vattøy, K.D., Smith, K. (2019). Students' perceptions of teachers' feedback practice in teaching English as a foreign language. Teaching and Teacher Education, 85: 260-268. https://doi.org/10.1016/j.tate.2019.06.024

[5] Yang, X.J. (2020). An Analysis of the Current Situation of English Teaching Quality in International Classes in Higher Vocational Colleges and a Study on Improving Strategies Taking the International Class of Civil Construction Engineering in Yangling Vocational and Technical College as an Example. Journal of Yangling Vocational \& Technical Colle ge, 19(3): 68-71+75. https://doi.org/10.19859/j.cnki.CN61-1403/G4.2020.03.020. https:// doi.org/10.22158/selt.v8n1p104

[6] Dendenne, B., Derakhshan, A. (2020). Autonomy, agency, and identity in teaching and learning English as a Foreign Language. System, 89: 1-3. https://doi.org/10.1016/ j.system.2019.102188

[7] Yang, X.F. (2019). On the Construction and Influencing Factors of SPOC-based College English Teaching Model. Journal of Sichuan International Studies University, 35(2): 146154. https://doi.org/10.3969/j.issn.1674-6414.2019.02.021 
[8] Luo, W., Zhang, Z.Z. (2020). Research on vocational English classroom teaching quality evaluation: current situation and strategies. Journal of Xiangyang Vocational and Technical College, 19(5): 66-68+96.

[9] Wang, D.Z. (2019). The Influence of Big Data on College English Teaching and Relevant Countermeasures. Journal of Hubei Open Vocational College, 32(24): 168-170. https://doi. org/10.3969/j.issn.2096-711X.2019.24.075

[10] Rus, D. (2020). Creative Methodologies in Teaching English for Engineering Students. Procedia Manufacturing, 46: 337-343. https://doi.org/10.1016/j.promfg.2020.03.049

[11] Petra, Z. (2015). The Issue of Need Analysis and Assessment of Quality in Teaching English for Medical Purposes. Procedia - Social and Behavioral Sciences, 174: 2995-3004. https://doi.org/10.1016/j.sbspro.2015.01.1040

[12] Yan, L.W., Kang, N., Gao, X.Y. (2020). The SPOC-based Construction of College English Teaching Quality Appraisal System. Journal of Changchun Education Institute, 36(3): 4045.

[13] Zhang, J.S. (2020). Evaluation of English Teaching Quality Based on GA Optimized RBF Neural Network. Computer Systems \& Applications, 29(3): 167-172. https://doi.org/10. 15888/j.cnki.csa.007302

[14] Wang, S.Q., Song, R. (2020). Evaluation of English teaching quality based on fuzzy comprehensive evaluation and bat algorithm. Information Technology, 44(4): 102-106. https://doi.org/10.13274/j.cnki.hdzj.2020.04.022

[15] Wolnowska, A.E., Konicki, W. (2019). Multi-criterial analysis of oversize cargo transport through the city, using the AHP method. Transportation Research Procedia, 39: 614-623. https://doi.org/10.1016/j.trpro.2019.06.063

[16] Calabrese, A., Costa, R., Levialdi, N., Menichini, T. (2019). Integrating sustainability into strategic decision-making: A fuzzy AHP method for the selection of relevant sustainability issues. Technological Forecasting and Social Change, 139: 155-168. https://doi.org/ 10.1016/j.techfore.2018.11.005

[17] Alfaro-Saiz, J.J., Bas, M.C., Giner-Bosch, V., Rodríguez-Rodríguez, R., Berdecho, M.J. (2020). An evaluation of the environmental factors for supply chain strategy decisions using grey systems and composite indicators. Applied Mathematical Modelling, 79: 490-505. https://doi.org/10.1016/j.apm.2019.10.048

[18] Bademlioglu, A.H., Canbolat, A.S., Kaynakli, O. (2020). Multi-objective optimization of parameters affecting Organic Rankine Cycle performance characteristics with Taguchi-Grey Relational Analysis. Renewable and Sustainable Energy Reviews, 117: 1-13. https://doi. org/10.1016/j.rser.2019.109483

[19] Kim, N., Park, J., Choi, J.J. (2017). Perceptual differences in core competencies between tourism industry practitioners and students using Analytic Hierarchy Process (AHP). Journal of Hospitality, Leisure, Sport \& Tourism Education, 20: 76-86. https://doi.org/10. 1016/j.jhlste.2017.04.003

[20] Karaman, A.S., Akman, E. (2018). Taking-off corporate social responsibility programs: An AHP application in airline industry. Journal of Air Transport Management, 68: 187-197. https://doi.org/10.1016/j.jairtraman.2017.06.012.

[21] Butdee, S., Phuangsalee, P. (2019). Uncertain risk assessment modelling for bus body manufacturing supply chain using AHP and fuzzy AHP. Procedia Manufacturing, 30: 663670. https://doi.org/10.1016/i.promfg.2019.02.094

[22] Singh, T., Patnaik, A., Chauhan, R. (2016). Optimization of tribological properties of cement kiln dust-filled brake pad using grey relation analysis. Materials \& Design, 89: 1335-1342. https://doi.org/10.1016/j.matdes.2015.10.045 
[23] Mazarbhuiya, R.M., Rahang, M. (2020). Surface modification of aluminium and its parametric optimization using grey relational analysis. Materials Today: Proceedings, 26: 1594-1597. https://doi.org/10.1016/j.matpr.2020.02.327

[24] Pandya, V.J., Rathod, P.P. (2020). Optimization of mechanical properties of green composites by gray relational analysis. Materials Today: Proceedings, 27: 19-22. https://doi.org/10.1016/j.matpr.2019.08.166

[25] Maghrabie, H.F., Beauregard, Y., Schiffauerova, A. (2019). Grey-based Multi-Criteria Decision Analysis approach: Addressing uncertainty at complex decision problems. Technological Forecasting and Social Change, 146: 366-379. https://doi.org/10.1016/ j.techfore.2019.05.031

[26] Kumar, J., Soota, T. (2020). Multi-response optimization of machining parameter for Zircaloy by response surface methodology and grey relation analysis. Materials Today: Proceedings, 21: 1544-1550. https://doi.org/10.1016/j.matpr.2019.11.084

\section{Author}

Nan Li was born in Xingtai City, Hebei Province, China. She received B.A. degree of English from Hebei University in 2003, M. A. degree of English Language and Literature from Hebei University in 2008, and $\mathrm{PhD}$ of Linguistics from Communication University of China in 2020. She started teaching career in July, 2003 in Xingtai University. Since 2003, she has published a book and more than 30 papers in English teaching and linguistics and hosted 11 projects and anticipated in more than 30 projects.

Article submitted 2020-11-07. Resubmitted 2020-12-07. Final acceptance 2020-12-10. Final version published as submitted by the authors. 